\title{
СНИЖЕНИЕ РИСКА ОШИБОК ПОСТРОЕНИЯ ГЕОЛОГИЧЕСКОЙ МОДЕЛИ СРЕДЫ ПРИ КОМПЛЕКСИРОВАНИИ ВОЛН РАЗНЫХ ТИПОВ И КЛАССОВ
}

Кузнечов B.M.

(Input Output Inc. - ВНИИГеофизика)

Резтоме. Применение определенных требований к технология работ уже начиная с этапа проектирования и проведения полевьг работ МBC позволяет повысить качество получаемьх результатов и закладывает базис для эффективной реализации разведочных критериев на основе априорной геологической модели с использованием комплексирования волн разньх типов. В частности, сочетание лучевого и конечно-разностного моделирования полного волнового поля позволяет оценить возможный генезис волн, ожждаемые соотношения кинематических и динамических параметров волн разньг типов и классов для различных удалений и оптимизировать схему наблюдений, ориентированную на реализацию ожидаемых разведочных критериев. Особую роль играет совершенствование технология обработки и интерпретащии данных МВС. Расширение типов и классов волн, присутствующих в волновом поле (PP,PS,PSS,SH,SV), при сопоставимом качестве их регистрации, в совокупности с комплексированием дифференциальных (скважинные данные) и интегральных (наземные данные) параметров позволяет определять (а не расчитывать) для динамической инверсин более широкий набор атрнбутов волнового поля. Трудносопоставимые по форме сигнала, амплитудам, пастотам и поляризации данные, полученные по отличающимся для разных типов волн временам вступлений для одноименных отражающих границ, после обработки по предлагаемым способам выводит решение обратных задач на новый уровень детальности и надежности в оценке модели среды.

Memod u результаты. Критическими точками в графе обработки данных монотипных поперечных и обменных волн разных классов являются реориентация компонент волнового поля в координаты ПВПII, оценка и коррекция статических поправок по S волнам и учет анизотропии в покрывающей толще. Комплексирование скважинных и наземных методов работах МBC уже на предварительной стадии обработки позволяет, помимо прочего, разобраться в природе волн. Фактически, корректная оценка генезиса волн определяет последующий граф их обработки и параметры обрабатываюших программ. Достаточно часто, даже при стандартных источниках возбуждения, в поле горизонтальных компонент присутствуют монотипные поперечные волны и волны, претерпевающие обмен на промежуточных границах [1]. Их ошибочно отождествляют с чисто обменными волнами и получают ложные объеты, участвующие в последующей интерпретации данных. Кроме того, привязка обменных волн к геологическим телам без скважинных данных достаточно субъективна и часто приводит к значительным ошибкам в структурных и атрибутных моделях.

Надежность оценки атрибутов S-волн (без их оценки невозможен переход к петрофизическим параметрам), сделанные по данным при их непосредственной регистрации, выше, чем их рассчет по амплитудам продольных волн в зависимости от удалений ПП-ПВ или по стохастическим зависимостям (Гринберг-Костагна и т.п.). По результатам обработки волн разньг типов и классов, отождествления и стратиграфической привязки наземных данных МВС в комплексе с данными ГИС и ВСП, получена структурная и скоростная модель разреза по волнам разных типов. Детализация разреза на более мелкие объекты осуществлялась на основе детального разделения сейсмических разрезов увязанных межцу собой волн разных типов с выявлением объектов разного ранга и масштаба, формируюших геологические разрезы. Это позволило оценить независимые упругие параметры для маломощного (30-60м) терригенного интервала разреза и выделить по совокупности отнотений разлнчных атрибутов волн разных типов (рис.1) песчанистое флюидонасыщенное тело на фоне вмешающих глинистых отложений. Для еще слабо изученньт частей разреза карбонатного рифея, с которыми могут быть связаны значмтельные перспективы обнаружения новых залежей нефти и газа, были разработаны разведочные критерии обнаружения зон возможного накопления УB по данным MBC.

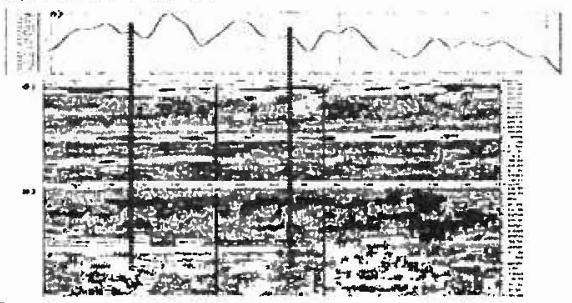

Рис. 1. Выделение песчанистого тела по сопоставленно отношений интервальных времен (a), мгновенных амплитуд (б) и частот (в) волн S и $\mathrm{P}$ для терригенных отложений девона.

Заключение. Приведенные результаты, полученные по данным работ МBC, проведенныг на юге Пермской области [2], показали высокую эффективность комплексирования волн разных тнпов и классов в освещении всего осадочного комплекса, характерного для южной части Русской платформы.

Автор выражает благодарность всем ООО «Пермнефтегеофизика» и GDS за плодотворное сотрудничество и предоставление необходимых данных.

\section{ЛИТЕРАТУРА:}

1. Шехтман Г.А., Кузнецов В.М., Жуков А.П. и др., Расширение типов волн, используемых в сейсморазведке: предпосылки и результаты., Технологии сейсморазведки, №2 2006, с ;

2. Кузнецов В. М, Шехтман Г.А., Коротков И.П., и др., Пример изучения венд-рифейского комплекса русской платформы технологией 2D-9C (МВC)., Технологии сейсморазведки, №4 2006 